\title{
KONTESTASI PEMIKIRAN DASAR NEGARA DALAM PERWUJUDAN HUKUM DI INDONESIA
}

\author{
oleh: \\ May Rosa Zulfatus Soraya \\ Fakultas Ekonomi dan Bisnis Islam UIN Sunan Kalijaga Yogyakarta \\ email: rosameymey@yahoo.co.id
}

\begin{abstract}
Abstrak: Pembentukan dasar negara menempati proses penting dalam sejarah kebangsaan. Dari sinilah kita dapat melihat negara ini mau dibawa ke mana oleh founding fathers. Saat menilik proses kesejarahan panjang itu, tergambar bahwa kontestasi pemikiran pembentukan dasar negara tidaklah sederhana. Para tokoh mencoba merebut simpati dan adu gagasan. "Pertaruangan" ide dan gagasan inilah yang menjadikan produk pemikiran dasar negara senantisa dinamis hingga saat ini. Apalagi dalam perbincangan negara berdasar Pancasila atau berdasarkan Islam. Peran tokoh nasionalis Islam sangat penting dalam perumusan dasar negara Indonesia. Terutama pada penghapusan kata-kata yang kurang berkenan pada butir pertama Piagam Jakarta, hal ini tidak lantas dipandang sebagai suatu kekalahan politik umat Islam. Sebaliknya hal ini harus dipandang sebagai sebuah sikap inklusif umat Islam yang hendak dikembangkan demi mewujudkan prinsip Islam sebagai suatu ajaran yang lebih mementingkan kemaslahatan bersama
\end{abstract}

Kata Kunci: Ide Dasar Negara, Pancasila, Nasionalis Islam,

\section{Pendahuluan}

Pada zaman penjajahan, rakyat Indonesia sangat gigih untuk memperjuangkan kemerdekaan bangsa Indonesia dari para penjajah. Pejuang bangsa Indonesia rela berkorban demi sebuah kemerdekaan untuk bangsa yang dicintainya. Para tokoh pejuang yang pandai duduk dalam posisi-posisi politik penting, baik dalam kabinet maupun memimpin perjuangan fisik dan diplomatik. Bahkan, banyak rakyat yang terlibat dalam perjuangan fisik melawan penjajah. Itu semua dilakukan semata-mata untuk berjuang demi meraih kemerdekaan bangsa.

Pada tahun 1942, Belanda pergi dan Jepang pun datang. Tiga setengah tahun lebih Jepang menjajah Indonesia lebih mengerikan daripada tiga setengah abad penjajahan Belanda. Segala kekayaan Indonesia dikuras habis. Bangsa Indonesia dihina dan dibiarkan berpakaian goni atau bagor. Tenaga kerja rakyat Indonesia dikuras habis-habisan (Kabul Budiyono, 2009: 16-17). Jepang memperlakukan rakyat Indonesia dengan tidak beperikemanusiaan.

Sebagai realisasi janji Jepang maka pada hari ulang tahun Kaisar Hirohito tanggal 29 April 1945 Jepang memberi semacam "hadiah ulang tahun" kepada bangsa Indonesia yaitu 
"kemerdekaan tanpa syarat". Tindak lanjut dari janji tersebut dibentuklah Dokuritsu Zyunbi Tioosakai atau Badan Penyelidik Usaha-usaha Persiapan Kemerdekaan Indonesia (BPUPKI) (Rukiyati, 2008: 45). Tujuan dari pembentukan badan ini adalah menyelidiki segala sesuatu mengenai persiapan kemerdekaan bangsa Indonesia.

BPUPKI melakukan sidang sebanyak dua kali yang berkaitan dengan penyusunan dan pengesahan dasar negara. Pada sidang BPUPKI pertama tanggal 29 Mei - 1 Juni 1945, Radjiman Wedyodiningrat selaku ketua BPUPKI, dalam pidato pembukaannya menyampaikan masalah pokok menyangkut dasar negara Indonesia. Muncul tiga tokoh nasionalis yang mengemukakan ide-ide pokok mengenai dasar negara Indonesia yaitu Mohammad Yamin, Supomo, dan Soekarno (Kabul Budiyono, 2009: 24).

\section{Ide Pokok Dasar Negara}

Ide-ide pokok dasar negara yang disampaikan pada saat pidato sidang BPUPKI pertama yaitu sebagai berikut: Mohammad Yamin adalah perikebangsaan, perikemanusiaan, periketuhanan, perikerakyatan, dan kesejahteraan rakyat. Ide-ide pokok dasar negara yang diutarakan oleh Supomo adalah persatuan, kekeluargaan, keseimbangan lahir dan batin, musyawarah, dan keadilan rakyat. Ide-ide pokok yang diutarakan oleh Soekarno adalah kebangsaan Indonesia, internasionalisme atau perikemanusiaan, mufakat dan demokratis, kesejahteraan sosial, dan ketuhanan yang berkebudayaan (Kabul Budiyono, 2009: 6-7). Rumusan ini oleh beliau atas petunjuk seorang ahli bahasa dinamakan Pancasila (Kabul Budiyono, 2009: 25). Jika anggota sidang tidak setuju dengan lima rumusan yang disampaikan oleh Soekarno di atas, maka rumusan itu dapat diperas menjadi tiga yang disebutnya Trisila, yaitu sosio-nasionalis, sosio-demokrasi, dan ketuhanan. Rumusan Trisila dapat pula diperas menjadi satu sila yang disebut oleh Soekarno sebagai Ekasila, yaitu gotong-royong. Menurut Soekarno gotong-royong adalah ide asli Indonesia (Rukiyati, 2008: 49).

Dalam sidang BPUPKI para anggota juga memperdebatkan tentang dasar negara, para anggota sidang BPUPKI mengajukan tiga hal yang berkenaan dengan dasar negara. Pertama, apakah Indonesia akan dijadikan sebagai negara kesatuan atau negara federal (bondstaat) atau negara perserikatan (statenbond). Kedua, masalah hubungan agama dan negara. Ketiga, apakah negara akan menjadi republik atau kerajaan (Choirun Niswah, 1999/2000:51. Saoki, 2014: 4).

Selain usulan yang disampaikan secara lisan (pidato), para anggota juga diminta memberi usulan secara tertulis. Kemudian, dibentuklah suatu panitia kecil berjumlah delapan 
orang (Rukiyati, 2008: 50). Panitia Kecil ini bertugas menampung saran-saran, usul-usul, dan konsepsi-konsepsi para anggota yang oleh ketua panitia telah diminta utuk diserahkan melalui sekretariat (Kabul Budiyono, 2009: 26).

Setelah para panitia kecil yang berjumlah delapan orang tersebut bekerja meneliti dan mengelompokkan usulan yang masuk, diketahui ada perbedaan pendapat dari para anggota sidang tentang hubungan antara agama dan negara. Para anggota sidang yang beragama Islam menghendaki bahwa negara berdasarkan syariat Islam, sedangkan golongan nasionalis menghendaki bahwa negara tidak berdasarkan hukum salah satu agama tertentu (Rukiyati, 2008:50).

Kelompok Islam menghendaki adanya persatuan antara negara dan agama Islam seperti tersirat dari ungkapan-ungkapan yang dikemukakan para tokohnya antara lain: “...hanya kemerdekaan yang berazaskan keislamanlah yang sesungguhnya melepasakan segala rakyat daripada perhambaan berbagai macam hal lainnya" atau "Ideologi kaum Muslimin dipadatkan oleh Quran" (Deliar Noer, 1982: 1. Sri Harini Dwiyatmi dkk, 2012: 19). Di lain pihak, golongan komunis menghendaki adanya pemisahan antara agama dan organisasi. Menganjurkan agar jangan mencampurkan agama dan perserikatan. Begitu juga kaum nasionalis berpendapat sama lebih jelas menyebut negara dipisahkan dari agama tertentu (Sri Harini Dwiyatmi dkk, 2012: 19).

Menurut Soekarno (dari kubu nasionalis) rencana UUD yang memuat persatuan agama dan negara tentu akan ditolak oleh badan perwakilan, bila dipaksakan berarti demokrasi ditinggalkan. Bagi beliau hanya ada dua alternatif dalam hubungan ini yaitu "persatuan staat-agama tetapi zonder democratie atau democratie tetapi staat dipisahkan dari agama?". Soekarno juga mengemukakan usulan mengenai dasar negara tentang sila ketuhanan, beliau mengatakan "prinsip Indonesia merdeka dengan bertakwa kepada Tuhan yang Maha Esa. Prinsip Ketuhanan! Bukan saja bangsa Indonesia ber-Tuhan tetapi masingmasing orang Indonesia hendaknya ber-Tuhan. Tuhannya sendiri. ... marilah kita semuanya ber-Tuhan. Hendaknya negara ialah negara yang yang tiap-tiap orangnya dapat menyembah Tuhannya dengan cara yang leluasa. Segenap rakyat hendaknya ber-Tuhan secara kebudayan, yakni dengan tiada 'egoisme agama' dan hendaknya negara Indonesia satu negara yang berTuhan" (Sri Harini Dwiyatmi dkk, 2012: 19-21).

Sejak itulah persoalan hubungan antara negara dan agama menjadi bahan wacana antara golongan nasionalis dan golongan Islam. Dari sisi kelompok Islam wacana tersebut mengarahkan pada cita-cita mendirikan negara Islam. 
Di Tanah Air sendiri, di saat perjuangan melawan penjajahan maupun pada awal kemerdekaan, polarisasi terjadi di antara dua kubu the founding fathers. Terjadi tarik menarik kepentingan antara banyak ideologi mengenai posisi agama di dalam negara. Perdebatan ini tidak berlangsung dalam satu waktu, melainkan dalam banyak babak (M. Rusli Karim, 199:21. Saoki, 2014:1-2). Begitu pula tatkala Indonesia membangun hubungan antara agama dan politik. Kesulitan ini pernah diungkapkan oleh Zifirdaus Adnan, ia menjelaskan bahwa hubungan ini begitu sulit sebab terdapat dua arus besar. Pertama, kelompok yang menghendaki adanya kaitan formal antara Islam dan Negara, baik dalam bentuk Negara Islam, Islam sebagai agama negara, atau negara yang memberlakukan ajaran Islam. Kedua, kelompok yang menantang kaitan antara Islam dan negara dalam bentuk apapun (Bahtiar Effendi, 2001: vvi. Saoki, 2014: 1-2). Hubungan yang tidak harmonis ini terutama disebabkan oleh perbedaan pandangan para pendiri negara ini. Salah satu butir terpenting dalam perbedaan di atas adalah apakah negara Indonesia bercorak Islami atau nasionalis (Bahtiar Effendi, 1998: 60. Saoki, 2014: 1-2).

Menurut Natsir, salah seorang tokoh Sarekat Islam, berupaya menghidupkan gagasan tentang keharusan memperjuangkan Islam sebagai dasar bagi Indonesia di masa depan. Beliau menentang gagasan Soekarno mengenai pemisahan antara urusan agama dan urusan negara. Terdapat dua alasan Natsir memperjuangkan Islam sebagai ideologi negara. Alasan pertama, karena Islam mengatur tidak saja soal hubungan manusia dengan Tuhan melainkan juga mengatur mengatur kehidupan sosial, politik, ekonomi, dll. Sudah menjadi tugas kaum Muslim untuk menjalankan amru bil ma'ruf wannahyu 'anil mungkar yang artinya adalah lakukan kebaikan dan hindari kejahatan. Semua aspek kehidupan haruslah dijalankan atas dasar prinsip tersebut, dengan al Quran dan Hadis Rasulullah SAW sebagai pedomannya. Alasan kedua, karena mayoritas penduduk Indonesia beragama Islam, sehingga ada kewajiban bagi mereka untuk menjadikan Islam sebagai ideologi negara (Sri Harini Dwiyatmi dkk, 2012: 20). Itu adalah alasan yang dikemukakan oleh Natsir mengapa menentang gagasan dari Soekarno.

Di lain pihak Soekarno, tetap pada pandangannya yaitu agama harus dipisahkan dari negara karena di masyarakat terdapat sejumlah ideologi seperti nasionalisme, Islam, dan komunisme, juga terdapat sejumlah agama yang dianut warga masyarakat. Soekarno mengungkapkan kekhawatirannya secara terbuka tentang implikasi-implikasi negatif yang muncul, apabila umat Islam Indonesia memaksakan kehendaknya (negara Islam), yakni pengakuan Islam secara legal formal di negara ini (Douglas E. Ramage, 1997: 29. Saoki, 2014: 10). Beliau cemas, kalau banyak bagian negara Republik Indonesia memisahkan diri, 
atau negara bekas jajahan Hindia Belanda seperti Irian Barat juga tidak ikut menggabungkan diri dengan Indonesia yang ber-ruh Islami ini (Douglas E. Ramage, 1997: 29. Saoki, 2014: $10)$.

Soekarno juga berpidato di Amuntai, Kalimantan. Beliau menyatakan bahwa: "negara yang kita inginkan adalah negara nasional yang mencakup seluruh bangsa Indonesia. Jika kita mendirikan negara berdasar Islam, beberapa wilayah yang penduduknya sebagian besar bukan Islam, seperti Maluku, Bali, Flores, Kepulauan Kai, Sulawesi, Papua akan memisahkan diri" (Sri Harini Dwiyatmi dkk, 2012: 60).

Pidato tersebut mengundang reaksi yang kurang berkenan di hati pemimpinpemimpin Islam, salah satu tokoh Masyumi mengecam pidato tersebut sebagai tidak demokratik, tidak konstitusional, dan bertentangan dengan ideologi Islam yang dianut oleh mayoritas warga negara Indonesia. Banyak organisasi dan partai Islam yang tidak setuju dengan pidato yang dikemukakan oleh Soekarno tersebut (Sri Harini Dwiyatmi dkk, 2012: 60). M. Isa Anshary juga menegaskan bahwa pidato tersebut tidak demokratis dan tidak konstitusional. Dalam nota protesnya kepada pemerintah ditegaskan bahwa pidato tersebut bukanlah suatu kebijaksanaan yang dapat dihargai, karena berisi penentangan terhadap ideologi Islam yang dianut oleh sebagian besar penduduk Indonesia (Saoki, 2014: 11).

Supomo menjabarkan tentang gagasan negara Islam dan gagasan negara yang berdasarkan cita-cita luhur dari agama Islam. Menurut beliau, di dalam negara yang tersusun sebagai negara Islam, negara tidak bisa dipisahkan dari agama. Negara dan agama adalah satu, bersatu padu ... dan hukum syariat itu dianggap sebagai perintah Tuhan untuk menjadi dasar yang dipakai oleh negara. Akan tetapi Supomo menganjurkan supaya negara Indonesia tidak menjadi negara Islam, tetapi menjadi "negara yang memakai dasar moral yang luhur yang dianjurkan juga oleh agama Islam” (A. Ubaedillah dan Abdul Rozak, 2010: 38). Alasan dari beliau mengapa negara Indonesia tidak menjadi negara Islam yaitu secara geografis Indonesia tidak terletak di lingkungan negara keislaman (corpus Islamicus), kita tidak perlu mewarisi pertikaian yang masih timbul di kalangan negara-negara Islam sendiri, dan jika kita mendirikan negara Islam berarti kita tidak mendirikan negara persatuan (Sri Harini Dwiyatmi dkk, 2012: 21).

Natsir menambahkan bahwa hanya dua alternatif yang dapat dijadikan dasar negara yaitu ideologi Islam atau ideologi sekuler, dengan sebuah kaedah ia menegaskan bahwa Islam dalam kaitannya dengan ibadah semua dilarang kecuali yang diperintahkan, sedangkan yang terkait dengan kehidupan dunia semua dibolehkan kecuali yang dilarang. Natsir menawarkan Islam sebagai azas negara bukanlah aksi pembangkangan negara (makar), akan tetapi lebih 
pada penghidupan demokrasi. Oleh sebab itu dalam pidatonya pada sidang pleno konstituante ia menghendaki negara Indonesia ini segabai "Negara demokrasi berdasarkan Islam" (Adnan Buyung Nasution, 1995:66. Saoki, 2014:12-13). Keinginannya ini Bukan sematamata karena Islam agama mayoritas di Indonesia melainkan ajaran Islam mengenai ketatanegaraan dan kehidupan bermasyarakat itu mempunyai sifat yang sempurna dalam menjamin kerukunan beragama dan bernegara (Adnan Buyung Nasution, 1995:66. Saoki, 2014:12-13). Achmad Zaini (NU) menegaskan bahwa Islam menjadi dasar negara bukan hanya karena fanatisme, akan tetapi karena tuntutan dan kewajiban terhadap penegakan hukum Allah SWT (Andree Feillard, 1999:54-55. Saoki, 2014:12-13).

Sementara itu, mengenai sistem pemerintahan suatu negara, Natsir berpendapat boleh meniru pemerintahan Barat asalkan tidak melanggar nilai-nilai dasar Islam. Karena baginya Islam tidak mempunyai sistem ketatanegaraan yang sempurna (Kamaruzzaman, 2001: 70. Saoki, 2014:12-13). Ini menarik untuk dicermati satu sisi Natsir terbuka untuk memakai sistem apa yang akan dipakai di Indonesia sisi lain dia bersikeras memperjuangkan Islam sebagai azas ideologi negara (Saoki, 2014: 12-13).

\section{Pancasila Vs Negara Islam}

Pandangan berbeda diungkapkan oleh fraksi Pancasila, ditegaskan bahwa pandangan ideologi Pancasila berasal dari kebudayaan dan masyarakat Indonesia yang beraneka ragam, Soekarno hanya menemukan, menggali, merumuskan unsur-unsur yang terdapat di dalamnya, menurut Suwirjo, Pancasila lahir dari rahim Ibu Indonesia. Tegasnya, Pancasila lebih dahulu ditemukan lahir, tumbuh dan berkembang yang akhirnya melahirkan Republik Indonesia (Saoki, 2014: 12).

Pemikir dan aktivis Islam seakan tidak ingin kalah dalam memberikan pendapatnya tentang pemisahan negara dan agama. Pemikir dan aktivis Islam malah memberikan pendapat yang sangat ekstrim yaitu mereka meyakini bahwa Islam tidak mengatur semua segi kehidupan. Islam hanya memberi nilai-nilai moral sebagai pedoman dasar dan umum bagi kehidupan manusia. Mereka berpendapat bahwa Islam tidak mewajibkan para pemeluknya untuk membentuk sebuah negara Islam, melainkan lebih menekankan pembentukan masyarakat yang baik yaitu masyarakat yang mencerminkan substansi peran universal Islam (Sri Harini Dwiyatmi dkk, 2012: 72).

Harun Nasution berpendapat mengenai hubungan Islam dan negara merupakan

tinjauan historis yang menghasilkarn sebuah kesimpulan bahwa dalam al-Quran tidak ditemukan ayat yang dengan tegas membicarakan soal pembentukan negara dan yang dengan 
tegas pula menjelaskan sistem pemerintahan yang harus berlaku dalam. Hal penting lainnya adalah dilaksanakanny ajaran Islam dalam masyarakat dan ajaran Islam berjalan dalam negara RI (Harun Nasution, 1991/1992: 222. Heni Wahyu Widayati, 2009: 218).

Untuk mengatasi perbedaan ini maka dibentuk lagi suatu panitia kecil yang yang berjumlah sembilan orang. Panitia ini dikenal dengan nama panitia sembilan (Rukiyati, 2008:50). Panitia Sembilan melakukan sidang pada tanggal 22 Juni 1945, menghasilkan kesepakatan atau persetujuan yang menurut istilah Soekarno adalah suatu modus, kesepakatan yang dituangkan di dalam Mukadimah (Preambule) Hukum Dasar, alinea keempat dalam rumusan dasar negara (Rukiyati, 2008: 51). Di dalam rancangan itu termuat rumusan kompromi antara pihak Islam dan pihak kebangsaan tentang hubungan antara negara dan agama, (Sri Harini Dwiyatmi dkk, 2012: 22) isi dari rumusan dasar negara yaitu ketuhanan dengan menjalankan syariat Islam bagi pemeluk-pemeluknya, kemanusiaan yang adil dan beradab, persatuan Indonesia, kerakyatan yang dipimpin oleh hikmat kebijaksanaan dalam permusyawaratan/perwakilan, dan keadilan sosial bagi seluruh rakyat Indonesia (Sri Harini Dwiyatmi dkk, 2012: 51). Mohammad Yamin mempopulerkan kesepakatan tersebut dengan nama Piagam Jakarta.

Rumusan Panitia Sembilan yaitu Piagam Jakarta tersebut diterima dengan baik dan dioper oleh Panitia Kecil dan dilaporkan kepada sidang pleno BPUPKI. Dengan demikian dapat dikatakan bahwa rumusan Dasar Negara yang terdapat di dalam Piagam Jakarta merupakan konsep resmi dasar negara bagi Indonesia merdeka (Kabul Budiyono, 2009: 28). Dengan selesainya BPUPKI menyusun rancangan UUD maka selesai sudah tugas dari BPUPKI. Bersamaan dengan keadaan-keadaan perang yang makin memburuk bagi pihak Jepang, maka Pemerintah Jepang di Indonesia membubarkan BPUPKI. Pada tanggal 9 Agustus 1945 membentuk dokuritsu Zyunbi Inkai atau Panitia Persiapan Kemerdekaan Indonesia (PPKI) (Kabul Budiyono, 2009: 30).

Sebelum PPKI dapat bekerja, Jepang telah dijatuhi bom atom di Nagasaki dan Hiroshima, sehingga pada tanggal 14 Agustus 1945 Jepang resmi menyerah pada tentara sekutu (Kabul Budiyono, 2009: 31). Pada saat bersamaan, kekosongan kekuasaan (vacum of power) tengah terjadi di Indonesia akibat menyerahnya Jepang pada tentara sekutu. Kekosongan kekuasaan ini tidak disia-siakan begitu saja oleh bangsa Indonesia. Situasi ini dimanfaatkan oleh kalangan pemuda Indonesia untuk mempersiapkan kemerdekaan bagi Indonesia. Tekad bulat untuk merdeka akhirnya terwujud pada tanggal 17 Agustus 1945 atas nama bangsa Indonesia, Soekarno dan Moh. Hatta membacakan teks proklamasi kemerdekaan (A. Ubaedillah dan Abdul Rozak, 2010: 39). 
KH. A. Wahid Hasyim adalah seorang tokoh wakil Islam dari NU. Pengorbanan beliau sangat pantas untuk dicatat dalam sejarah bangsa Indonesia, karena beliau dan golongan Islam menghapus tujuh kata Piagam Jakarta. KH. A. Wahid Hasyim menunjukkan fleksibilitas namun ketika satu hari setelah kemerdekaan diproklamasikan, dia menerima untuk menggugurkan Piagam Jakarta dari konstitusi. Wilayah berpenduduk Kristen telah menyampaikan pesan kepada Mohammad Hatta bahwa mereka tidak akan bergabung dengan sebuah republik yang menunjukkan identitas Islam seperti itu, empat pimpinan Islam termasuk KH. A. Wahid Hasyim dari NU menyetujui kompromi tersebut. Terlebih lagi KH. A. Wahid Hasyim mengusulkan kepada para pimpinan Islam untuk mengubah asas ketuhanan dengan ditambah kata-kata yang Maha Esa (satu dan hanya satu-satunya), suatu rumusan yang berimplikasi tauhid: (monoteisme) bagi umat Islam (Deliar Noer, 1990:255. Saoki, 2014: 4).

Kesiapan berkompromi ini nampaknya didasarkan pada pemahaman yang relatif liberal terhadap Piagam Jakarta, (Andree Feillard, 1996:8. Saoki, 2014:4) K.H. A. Wahid Hasyim telah menjelaskan sikapnya dengan argumen berikut: Pertama, kondisi saat itu sangat membutuhkan persatuan untuk menghadapi Belanda yang berusaha kembali ke daerah jajahan mereka, kedua dia telah menerima dengan pemahaman, bahwa kewajiban mengikuti syariah Islam bagi umat Islam akan mendapatkan tempatnya dalam penerapan yang jujur terhadap pasal 29 UUD 1945 yang menjamin kebebasan setiap warga negara untuk memeluk agama dan mengamalkan menurut agamanya masing-masing (Saifuddin Zuhri, 1987: 302. Saoki, 2014:4). Pada pasal yang telah menunjukkan "kebebasan” sedangkan Piagam Jakarta mengatakan "kewajiban", nampak bahwa KH. A. Wahid Hasyim memiliki penafsiran yang fleksibel terhadap Piagam Jakarta yang kabur batasannya, dan bukan yang lebih kaku yang ditakuti beberapa kalangan akan dipaksakan Islam (Saifuddin Zuhri, 1987:300-302. Saoki, 2014:4).

KH. A. Wahid Hasyim, yang oleh Harry J. Benda disebut sebagai wakil Islam paling terkemuka pada masa akhir pendudukan Jepang, (Saoki, 2014:4) menunjukkan jalan pikiran moderat yang mendahulukan kepentingan umum daripada kepentingan pribadi atau kelompok. Ia menginginkan persatuan umat, baik sesama umat Islam, maupun dengan umat agama lain dalam bingkai negara Indonesia.

Mengenai peristiwa penghapusan tujuh kata itu, dalam perbincangan dengan Saifuddin Zuhri, ia hanya berharap: "Yang harus dijaga, jangan sampai umat Islam tidak memperoleh hak-hak mereka secara politis. Jika perang sudah usai, jika fase perjuangan mati hidup sudah dilewati, tentu orang mulai mengisi kemerdekaan dengan usaha-usaha 
membangun bangsa dan negara. Moga-moga saja saham umat Islam di masa paling sulit itu tidak dilupakan...” (Saoki, 2014:4).

Persoalan mendasar bukanlah bagaimana mendirikan sebuah negara Islam, tetapi Keutamaan Islam pada hakikatnya adalah persaudaraan, keadilan, dan kebaikan budi pekerti. Demikian dikatakan KH. A. Wahid Hasyim dalam sebuah tulisannya di Mimbar Agama tahun 1951 (Saoki, 2014:4).

Sebagian rakyat Indonesia berkeinginan menghidupkan syariah Islam dengan mewujudkan negara Indonesia sebagai negara Islam, tetapi dengan lahirnya Republik Indonesia harus diterima, yang terpenting di dalamnya, kaum Muslimin dapat melaksanakan ajaran agamanya secara nyata. Dicantumkannya sila Ketuhanan Yang Maha Esa dan dasar demokrasi (kedaulatan rakyat) dalam Pancasila memberikan pegangan kepada bangsa Indonesia untuk memberikan kebebasan dan kemerdekaan suatu golongan kepada golongan lain. Pertemuan dua prinsip ini, menurut KH. A. Wahid Hasyim, mengakibatkan adanya kompromi, keinginan kaum Muslimin untuk menghidupkan syari'at agamanya diberi jalan, tetapi prinsip demokrasi juga dipertahankan agar keinginan tadi tidak mendesak dan merugikan golongan lain (Saoki, 2014:4).

Perdebatan yang terjadi antara pendukung Pancasila sebagai dasar negara dengan pendukung Islam, pada dasarnya merupakan konfrontasi ideologi, karena masing-masing pihak mengajukan argumentasi yang tajam mengenai keunggulan ideologi yang didukungnya. Pada satu sisi, Pancasila dianggap sebagai platform sejati untuk setiap ideologi yang terdapat di Indonesia dan sesuai dengan kepribadian bangsa Indonesia, dan hanya ideologi Pancasila yang dapat menjamin kesatuan dan keutuhan masyarakat (Saoki, 2014:14).

Pandangan-pandangan mengenai Pancasila sebagai dasar negara diulang berkali-kali dan dikembangkan dengan berbagai variasi selama perdebatan berlangsung, sejak awal perdebatan sudah dinyatakan bahwa mengubah Pancasila sebagai dasar negara akan dianggap sebagai pengkhianatan terhadap perjuangan revolusioner dan membahayakan perdamaian dan kesatuan Indonesia (Saoki, 2014:14).

Pada tanggal 18 Agustus 1945 Pancasila ditetapkan sebagai dasar negara sebagaimana termuat dalam Pembukaan UUD 1945 dan menetapkan UUD 1945 itu sendiri. Pancasila yang artinya "lima dasar" memiliki maksud "satu dasar negara yang terdiri atas lima unsur yang menjadi satu kesatuan dasar filsafat negara Republik Indonesia" (Noor M. Bakry, 2010: 18). Pancasila dasar negara Indonesia yang tertera dalam alinea keempat pembukaan UUD 1945 adalah Ketuhanan Yang Maha Esa, Kemanusiaan yang Adil dan 
Beradab, Persatuan Indonesia, Kerakyatan yang Dipimpin oleh Hikmat Kebijaksanaan dalam Permusyawaratan/Perwakilan, dan Keadilan Sosial bagi Seluruh Rakyat Indonesia. Dengan ditetapkannya Pancasila sebagai dasar negara oleh PPKI tanggal 18 Agustus 1945, maka selesai sudah satu babakan sejarah perjuangan bangsa Indonesia untuk merumuskan dasar bagi penyelenggaraan negara merdeka yang sudah lama dicita-citakan (Sri Harini Dwiyatmi dkk, 2012: 39-40).

Pasca terhapusnya tujuh kata dalam Piagam Jakarta pada sidang PPKI tanggal 18 Agustus 1945, membuat sebagian kelompok Islam kecewa. Namun seiring berjalannya waktu, mereka 'terpaksa' menerima kenyataan tersebut. Sebenarnya, makna perubahan di masa-masa kritis tersebut cukup jelas, yakni: mustahil negara Indonesia diubah menjadi negara Islam karena sangat berlawanan dengan konstitusi yang baru dibentuknya. Pada tahun 1978, Alamsyah Ratu Perwiranegara (Menteri Agama saat itu) mengatakan bahwa hal itu sudah tepat untuk menjaga persatuan Indonesia. Bukankah sila Ketuhanan yang Maha Esa terilhami dari konsep tauhid? Hal ini menunjukkan bahwa loyalitas umat Islam di Indonesia terhadap Pancasila tidak perlu dipertanyakan lagi (Ahmad Syafii Maarif, 1985:109-110. Muhammad Ali Chozin, 2009:14). Pancasila sebagai dasar kerohaniaan Negara Kesatuan Republik Indonesia (NKRI) bersumber dari unsur-unsur dalam Pembukaan Undang-undang Dasar (UUD) 1945. Berdasarkan unsur-unsur tersebut, menurut para ahli hukum tata negara bahwa pembukaan UUD 1945 pada hakikatnya telah memenuhi syarat sebagai kaidah negara yang fundamental (staatsfundamentalnorm) (Muhammad Ali Chozin, 2009: 14).

Diterimanya Pancasila sebagai asas dan ideologi negara merupakan puncak dari pertentangan dan sekaligus menunjukkan kekalahan kelompok Islam yang harus berkompromi dengan kepentingan lain. Umat Islam yang sebelumnya memperjuangkan ideologi Islam sebagai dasar negara dalam Mukadimah UUD 1945 harus mengalah dengan Pancasila. Keinginan keras umat Islam saat itu bisa dimaklumi, selain sebagai pejuang mayoritas kemerdekaan, Pancasila sendiri menyimpan dua faktor yang sangat debatable. Pertama, tentang kandungan Pancasila itu sendiri. Kedua, tentang makna penting Pancasila jika dibanding dengan agama (Deliar Noer, 1983:108. Saoki, 2014:6).

Rela menerima gagasan atau pandangan orang lain, sekalipun gagasan atau pandangan tersebut dari golongan minoritas dan mengorbankan milik pribadi atau kelompoknya sekalipun itu dari golongan mayoritas asalkan untuk kemaslahatan bersama hal tersebut jauh lebih mulia dan terhormat. Hal seperti itu juga telah ditunjukkan secara terhormat oleh para pendiri bangsa Indonesia di masa lalu. Menurut catatan dari rohaniawan Franz Magnis Suseno, salah satu peristiwa penting dalam catatan sejarah bangsa Indonesia 
yang dapat dijadikan contoh untuk pendewasaan warga negara Indonesia yaitu kesediaan kelompok nasionalis Islam dalam persidangan BPUPKI menerima kelima sila dalam Pancasila sebagai dasar negara dan tidak menuntut tempat khusus bagi umat Islam dalam konstitusi negara, padahal mereka mewakili kelompok dominan (A. Ubaedillah dan Abdul Rozak, 2010:45).

Tujuan awal dari Pancasila adalah untuk memberikan dasar bersama bagi penegakan suatu negara yang merdeka, bersatu, dan modern di bekas jajahan Belanda. Pancasila dirasa cocok untuk bangsa Indonesia tanpa memandang agama, etnisitas atau daerah. Karena itu, nilai sosial terpenting Pancasila adalah toleransi. Meski Indonesia secara filosofis didasarkan pada agama, tetapi negara tidak mendukung salah satu agama. Dalam memahami Negara Pancasila, Abdurrahman Wahid mengatakan bahwa:"Tanpa Pancasila, negara RI tidak akan pernah ada. Karena Pancasila adalah serangkaian prinsip-prinsip yang bersifat lestari. Ia memuat ide yang baik tentang hidup bernegara yang mutlak diperjuangkan. Saya akan mempertahankan Pancasila yang murni dengan jiwa raga saya, terlepas dari kenyataan bahwa ia tidak jarang dikebiri atau dimanipulasi, baik oleh segelintir tentara maupun sekelompok umat Islam” (Douglas E. Ramage, 1997:101. Muhammad Ali Chozin, 2009: 17).

Muhammad Ali Chozin menguraikan satu persatu sila-sila yang termasuk dalam Pancasila dan bandingkan dengan syari'at Islam yang digembor-gemborkan oleh partai atau kelompok-kelompok Islam yang setengah-setengah dalam memahami keistimewaan Pancasila (Muhammad Ali Chozin, 2009: 18).

Sila pertama, Ketuhanan Yang Maha Esa (Yudi Latif, 2007: 17. Muhammad Ali Chozin, 2009:18). Dalam sila ini jelas-jelas mengajarkan keimanan dan ketauhidan. Berdasarkan hal ini, maka rakyat Indonesia dituntut untuk mengimani adanya Tuhan pencipta alam semesta yang tunggal dan dengan begitu kita dituntut untuk beribadah sesuai dengan agama dan kepercayaannya masing-masing. Dengan dibebaskannya mereka untuk menjalankan ibadahnya masing-masing, menghornati dan menghargai ritual keagamaannya, maka kita sudah melaksanakan sebuah rasa toleransi dan berjiwa pluralisme. Tidak hanya itu saja, kitapun diperbolehkan untuk menjalin kerjasama dengan pemeluk agama lain dan sekaligus tidak memaksakan kepercayaan serta keyakinan yang kita anut kepada orang lain.

Sila kedua, Kemanusiaan yang adil dan beradab. Dalam sila ini bermakna bahwa bangsa Indonesia menjunjung tinggi nilai-nilai kemanusiaan. Dengan memperlakukan manusia secara adil, tidak berat sebelah, jujur, memperlalukan sama terhadap semua manusia, sehingga akan melahirkan manusia yang beradab, sopan santun dalam perkataan dan pergaulan. Dengan begitu akan melahirkan persamaan derajat, hak, dan kewajiban antar 
sesama manusia,saling mencintai satu sama lain, mengembangkan sikap tenggang rasa, dan berani membela kebenaran dan keadilan.

Sila ketiga, Persatuan Indonesia. Dalam sila ini terkandung makna untuk menghindari perpecahan hanya karena perbedaan ras, suku, agama, maupun tradisi dan budaya. Dengan begitu, Indonesia akan menjadi negara yang berdaulat, utuh, dan sekaligus menjadi contoh kerukunan antara warga negara. Melalui implementasi cinta tanah air dan bangsa, bangga menjadi bangsa Indonesia; rela berkorban untuk kepentingan bangsa dan negara, serta memajukan pergaulan demi kesatuan yang berpegang pada semboyan Bhineka Tunggal Ika.

Sila keempat, Kerakyatan yang dipimpin oleh hikmah kebijaksanaan dalam permusyawaratan/perwakilan. Di dalam sila ini bermakna bahwa kedaulatan tertinggi negara berada di tangan rakyat, melalui wakil-wakilnya yang terpilih di parlemen melalui pemilu yang jujur, adil, bebas, rahasia, dan langsung dengan dikendalikan pikiran yang jernih, logis, dan penuh tanggungjawab kepada Tuhan dan rakyat yang diwakilinya. Melalui implementasi tidak memaksakan kehendak kepada orang lain, tidak melakukan intimidasi keputusan kepada yang tidak sepakat, menjunjung tinggi nilai-nilai musyawarah mufakat, dan menerima dengan lapang dada atas keputusan bersama dengan menjalankan hasilnya secara penuh tanggungjawab.

Sila kelima, Keadilan bagi seluruh rakyat Indonesia. Dalam sila ini menyarankan rakyat Indonesia untuk saling membantu dan gotong royong, giat dan ulet dalam belajar dan bekerja, lebih besar rasa optimisnya daripada rasa psimisnya, tidak menjadi pembajak atau plagiat dari karya orang lain, tidak melakukan pemalakan/pemerasan dan perbuatan yang merugikan kepentingan umum, serta tidak bergaya hidup mewah dan boros.

\section{Penutup}

Menjadi bangsa Indonesia tidak berarti meninggalkan kekhasan yang telah melekat pada masyarakat Indonesia seperti suku, budaya, bahasa, keyakinan d.l.s.b., tetapi unsurunsur ini hendaknya melebur ke dalam kemajemukan bangsa Indonesia. Kekhasan ini merupakan pupuk penyubur bagi bangsa Indonesia yang majemuk. Kemajemukan ini haruslah berjalan dengan serasi di tengah-tengah pentingnya memelihara persatuan dan kesatuan sebagai bangsa Indonesia yang merdeka dan utuh. Tanpa adanya kerelaan dan kesediaan dari setiap warga negara Indonesia untuk menjadikan Pancasila sebagai ikatan bersama dalam kehidupan berbangsa dan bernegara di Indonesia, maka masyarakat Indonesia 
tidak mudah untuk naik kelas menjadi sebuah bangsa (nation) dan akan mudah tercerai-berai (A. Ubaedillah dan Abdul Rozak, 2010: 45).

Tumbuhnya keberagamaan yang inklusif diharapkan bangsa Indonesia bisa membawa rakyatnya kepada suasana yang adil dan sejahtera, tanpa harus memaksakan kehendak untuk menerapkan syari'at Islam ke ranah publik dan negara. Agama adalah urusan pribadi antara makhluk dengan Tuhan, sedangkan negara adalah urusan semua warga negara yang hidup dalam suatu negara yang sama dengan dasar hukum yang sama pula. Semoga dengan masih berlakunya Pancasila di Bumi Nusantara, maka Negara Indonesia ini akan tetap berdiri sebagai negara yang bermartabat tanpa harus menindas dan mendiskriminasikan suatu kelompok, ras, suku maupun keyakinan orang lain. (Muhammad Ali Chozin, 2009: 29).

Peran tokoh nasionalis Islam sangat penting dalam perumusan dasar negara Indonesia. Terutama pada penghapusan kata-kata yang kurang berkenan pada butir pertama Piagam Jakarta, hal ini tidak lantas dipandang sebagai suatu kekalahan politik umat Islam. Sebaliknya hal ini harus dipandang sebagai sebuah sikap inklusif umat Islam yang hendak dikembangkan demi mewujudkan prinsip Islam sebagai suatu ajaran yang lebih mementingkan kemaslahatan bersama. Kesepakatan para tokoh Islam dengan kalangan nasionalis sekuler untuk mengganti kata-kata pada butir pertama Piagam Jakarta dengan Ketuhanan Yang Maha Esa dapat dikatakan dengan makna tauhid dalam agama Islam. Menjadikan Pancasila sebagai dasar negara NKRI adalah sebuah kesepakatan nasional yang harus dipegang teguh sampai kapanpun oleh semua warga negara Indonesia. Jadikanlah hal tersebut sebagai suatu jihad terhadap bangsa Indonesia yang harus dipertahankan sampai kapan pun. Bangsa Indonesia harus selalu menjadi satu kesatuan yang bulat dan utuh, tidak boleh terpecah belah. Sesuai dengan semboyan bagsa Indonesia yaitu Bhinneka Tunggal Ika yang artinya bercerai kita runtuh, bersatu kita teguh.

\section{Daftar Pustaka}

Bakry, Noor M. 2010. Pendidikan Pancasila, Yogyakarta: Pustaka Pelajar.

Budiyono, Kabul. 2009. Pendidikan Pancasila untuk Perguruan Tinggi. Bandung: Alfabeta.

Choirun Niswah. 1999/2000. “KH.A. Wahid Hasyim dan Pancasila; Studi Atas Pemikirannya Tentang Dasar Negara (1945-1953), Laporan Penelitian, IAIN Raden Fatah Palembang. 
Chozin, Muhammad Ali. 2009. "Peran Asas Tunggal Pancasila dalam Membendung Gerakan Ideologi Islam Garis Keras”. Jurnal Islam-Indonesia, Volume 01. Nomor 01.

Dwiyatmi, Sri Harini dkk. 2012. Pendidikan Kewarganegaraan. Yogyakarta: Pustaka Pelajar.

Effendi, Bahtiar. 1998. Islam dan Negara: Transformasi Pemikiran dan Praktek Politik Islam di Indonesia. Jakarta: Paramadina. , 2001. Teologi Baru Politik Islam, Yogyakarta: Galang Press.

Feillard, Andree. 1999. NU vis a vis Negara Pencairan Isi, Bentuk dan Negara. Yogyakarta: LKIS.

Kamaruzzaman. 2001. Relasi Islam dan Negara: Perspektif Modernis dan Fundamentalis. Magelang: IndonesiaTera.

Karim, M. Rusli. 1999. Negara dan Peminggiran Islam Politik, Yogyakarta: Tiara Wacana.

Latif, Yudi. Dialektika Islam: Tafsir Sosiologis atas Sekularisasi dan Islamisasi di Indonesia. Yogyakarta: Jalasutra.

Ma'arif, Ahmad Syafi'i. 1996. Islam dan Politik: Teori Belah Bambu Masa Demokrasi Terpimpin 1959-1965, Jakarta: Gema Insani Press.

Nasution, Adnan Buyung. 1995. Aspirasi Pemerintahan Konstitusional di Indonesia: Studi Sosio-Legal atas Konstituante 1956-1959. Jakarta: Grafiti Press.

Nasution, Harun, 1991/1992. "Hubungan Islam dan Negaraf', dalam Departemen Agama, Kajian Agama dan Masyarakat: 15 Tahun Badan Penelitian dan Pengembangan Agama 1975-1990. Jakarta: Badan Penelitian dan Pengembangan Agama Depag RI.

Noer, Deliar. 1983. Islam, Pancasila dan Asas Tunggal. Jakarta: Yayasan Perkhidmatan. , 1982. Gerakan Modern Islam Di Indonesia 1900-1942. Jakarta: LP3ES.

Ramage, Douglas E. 1997. Percaturan Politik di Indonesia: Demokrasi, Islam dan Ideologi Toleransi, terj. Hartono Hadikusumo. Yogyakarta: Matabangsa.

Rukiyati dkk. 2008. Pendidikan Pancasila Buku Pegangan Kuliah. Yogyakarta: UNY Press.

Saoki. 2014. Islam sebagai Dasar Negara (Perdebatan dalam PPKI dan Konstituante). http://fish.uinsby.ac.id/?p=1764, unduh, 13 Desember 2014.

Ubaedillah, A. dan Abdul Rozak. 2010. Pendidikan Kewarganegaraan Demokrasi, HAM, dan Masyrakat Madani. Jakarta: ICCE dan Kencana.

Widayati, Heni Wahyu. 2009. "Dialog Pemikiran tentang Islam dan Negara di Indonesia Masa Awal Kemerdekaan”. Jurnal Dakwah, Vol. X No. 2. Juli-Desember.

Zuhri, Saifuddin. 1987. Berangkat dari Pesantren. Jakarta: Gunung Agung. 
